\title{
Going Global and Getting Graphic: Critical Multicultural Citizenship Education in an Afterschool Program for Immigrant and Refugee Girls
}

\author{
Jie Y. Park \\ Clark University \\ U. S. A.
}

ABSTRACT: This qualitative case study reports on the experiences of six recent-arrival immigrant and refugee girls as they participated in an afterschool program designed to promote critical multicultural citizenship through graphic novels. Analysis of discourse data revealed how the girls explored the interdependence among nation-states and wrestled with the complexities in their new home country. The study's findings challenge deficit perspectives that immigrant youth, who are learning English, are not ready to engage in deliberative discourse around social and global issues. The findings offer a different way of thinking about citizenship education for recent-arrival immigrant youth.

KEYWORDS: critical multiculturalism, citizenship education, English learners, immigrant youth, graphic novels

\author{
Framing Critical Multicultural Citizenship Education \\ Afterschool Program: Context and Participants \\ Methodology, Data Sources, and Analysis \\ Findings \\ Conclusion \\ Notes \\ References \\ Author Contact
}

When we came in here, my family, it's totally different. We have a black people in my country but not a lot. So we never imagined. We've never seen like a white person with a black person (Maryam).

Despite the resilience of recent-arrival refugee and immigrant youth, they struggle with feelings of dislocation and discrimination (Suárez-Orozco, Suárez-Orozco, \& Todorova, 2008). Moreover, because recent-arrival immigrant youth are likely to be English language learners, they often struggle to give voice to their ideas and feelings in English-dominant school settings (Fu \& Graff, 2008). I began this paper with a quote from Maryam (all names are pseudonyms), a refugee youth from Jordan. In 2014 Maryam and her family came to the United States. As a recent arrival to the United States, Maryam faced a set of new experiences: she had to communicate with boys in her school and with classmates who come from different parts of the world. In 
discussing her specific concerns about life in the United States, Maryam described how her parents fear she will be mistreated in and out of school because she wears a hijab (veil). She also described the challenges of asserting her voice in school, saying, "I used to be, in my school with my friends, actually in my language, talk a lot. Like say what I feel exactly. But when I came here, English makes me quiet. Not speak a lot. Can't joke."

This paper is based on two premises. First, immigrant youth need opportunities to engage in dialogue where they grapple with what it means to belong to, and lead powerful lives in, their new country. Second, this kind of dialogue is crucial to fostering critical multicultural citizenship. That is, in order to foster critical multicultural citizenship in immigrant and refugee youth, we need to shift away from pedagogies centered on facts about the U.S. government or exercises aimed at instilling patriotism (e.g., pledging allegiance to the flag) towards a pedagogy that leverages dialogue about democratic values like equality and justice. Yet in U.S. schools that serve large numbers of English language learners and first-generation immigrants, opportunities for dialogue are scarce in classrooms ${ }^{1}$ (Valdés, 1998). Youth are more likely to be engaged in classroom activities that focus on the "basics" of language acquisition, like memorizing vocabulary. Furthermore, when it comes to citizenship education, most immigrant youth are exposed to curricula that uphold a homogeneous view of citizenship. As Salinas, Sullivan, and Wacker (2007) argue, much of school-based citizenship education in the United States overlooks the possibilities and tensions associated with diverse cultural, national, and global identities. Embedded in many social studies, government, history, and geography lessons are notions of citizenship that are static and bound to geophysical borders. In fact, analyzing texts and programs for citizenship education, Abowitz and Harnish (2006) found that transnational and critical discourses have yet to alter the dominant framing of citizenship education.

In this paper, I report on the experiences of six high-school aged girls as they participated in an afterschool literacy program for immigrant girls. A high school teacher (Anglo-American woman) and I (woman of color, daughter of immigrants, and teacher educator) have been facilitating an afterschool program aimed at promoting critical multicultural citizenship through discussing graphic novels-defined as a "book-length sequential art narrative" (Carter, 2007, p. 1).

In the first section, I conceptualize critical multicultural citizenship education (Banks, 2004; Castro, 2009; Dilworth, 2004) and describe how the program was shaped by the frameworks of critical multicultural education and critically conscious citizenship education (Salinas, Sullivan, \& Wacker, 2007). Next I describe the afterschool program and participants and discuss my approach to researching the program. This is also where I describe my positionality and epistemology. Then I portray how the girls, motivated by the content of the graphic novels and supported by the environment of the afterschool program, shared stories about their countries and governments; became aware of and, at times, questioned cultural stereotypes; and gained understanding into the complexity of the world. I conclude by arguing for a critical multicultural approach to citizenship education that foregrounds student-driven dialogue and leverages multimodal texts. I also work to debunk the deficit perspective that immigrant youth, who are learning English, are not ready to engage in deliberative discourse around social 
and global issues, or analysis of political systems and historical events. Ultimately, I want to offer a different way of thinking about citizenship education for late arrival immigrant youth - a way that begins with what they know about their own countries and governments, not with what they do not yet know about the United States.

\section{Framing Critical Multicultural Citizenship Education}

In this paper I challenge citizenship education that is based on a banking model (Freire, 1999) in which adults teach facts about United States history and government, or transmit traits of "good" citizenship (e.g., voting, performing community service). In place of a transmission- or assimilationist-approach to citizenship education, I draw on the work of those who theorize citizenship education as critical and multicultural.

Critical multicultural citizenship has been shaped by the writings of scholars (Nieto, 2002; Sleeter \& Bernal, 2004) who are committed to fostering critical reflection and consciousness and promoting justice and equity. According to Nieto (2002), critical multiculturalism is anti-racist, centered on the perspectives and knowledge of diverse groups of people, and important for all students. Critical multicultural citizenship also draws from the work of critical pedagogy-namely its focus on the transformative potential of education. An approach to education, critical pedagogy helps students to identify, question, and reimagine social practices, structures, and ideologies that uphold oppression (Giroux, 2004; Kincheloe, 2008). Critical multicultural citizenship education aims to support students in becoming "ethical subjects of history" (McLaren, 1997, p. 238) and cultural beings with the power to name, question, and transform their worlds.

In addition to interrogating injustices and transforming the status quo, critical multicultural citizenship education promotes meaningful relationships between individuals who do not share social locations. These relationships, I believe, are created and sustained in/through dialogue. It follows, then, that critical multicultural citizenship education is shaped by a commitment to and belief in transformative dialoguedialogue in which participants question and support each other in the service of constructing different understandings of the self, others, and the world. The centrality of dialogue in multicultural citizenship education will be highlighted throughout this article.

Through dialogue, participants are exposed to multiple perspectives, which, in turn, facilitate deeper understandings of reality (Nieto, 2002). When we encounter multiple or even conflicting perspectives, we not only clarify our beliefs, but also become more aware of alternatives (Delgado, 1998). I would add that dialogue supports questioning and transforming reality. Although some have pointed to the lack of empirical evidence on whether and to what extent dialogue mitigates systemic inequities (Schoem, 2003), I support the view that "youth and adults interact[ing] with each other in meaningful work and talk may be a critical first step for building engaged, diverse democratic publics" (Abu El-Haj, 2007, p. 312). In meaningful talk, participants learn to listen to one another, which is an "exercise in recognition" (hooks, 1994, p. 41). Such recognition is necessary for building engaged democratic spaces. 
To be clear, not every dialogic interaction prompts self-reflexivity and critical inquiry into the world. Discussing the conditions under which dialogue can become transformative, DeNicolo and Franquiz (2006) focus on what motivates powerful talk, specifically the role of the textual tool-in their case, multicultural children's literaturein creating critical encounters. Critical encounters refer to moments when something from the text "surprises, shocks, or frightens the reader or readers to such a degree that they seek to inquire further" (DeNicolo \& Franquiz, p. 157) not just into the text, but into their own and others' ways of understanding the word and world (Freire, 1987). Drawing on DeNicolo and Franquiz's concept of critical encounters, I show how the girls, in reading and discussing graphic novels, wrestled with not only issues of citizenship, national identity, belonging, and power, but also the realities of living in and learning a new land.

\section{Afterschool Program: Context and Participants}

The six girls in the afterschool program attend Gateway, an urban school (Grades 7-12) in the U.S. Northeast. For 72 percent of the 497 students, English is not their first language. Eighty-nine percent receive free lunch. Ms. Lana, an ESL teacher at Gateway, is a co-designer and facilitator of the program, which, at the time of publication, is in its third year.

Although there are different programs and curricula for citizenship education (see Levine \& Higgins-D'Alessandro, 2010), Ms. Lana and I decided on an all-girls graphic novel club. We wanted the program to be dialogue-based because we believe that we cannot re-imagine our ways of seeing the world without the voices of others. We decided on graphic novels because multimodal texts, which "incorporate... visual images and graphic design elements, along with written texts" (Serafini, 2011, p. 342) build on the literate resources of many $21^{\text {st }}$ century youth. Lastly, we created a program for girls because of our own gender identity and our observations that immigrant girls were often positioned as silent in the school.

At the start, Ms. Lana recruited five girls to join. The girls' home languages included Spanish, Arabic, French, and Mandarin. When we began to meet in January of 2014, Maryam had been in the country for less than nine months, and Alisha for three years. The other participants' time in the United States fell somewhere in between. Participation has remained stable, although Alisha left the group after eight months. She was replaced by Danielle, who is the only participant born in the United States. In January 2015, Monique, new to Gateway, joined.

We meet every Friday after school. The meetings last approximately two hours. Ms. Lana and I involve the girls in the text-selection process by asking them what genres and issues interest them. Based on their feedback, we select three titles and give brief book talks before voting on the text. It takes five to six meetings to discuss one graphic novel ${ }^{2}$. As facilitators, the adults decide on the number of pages to read for the following week. Although some of the discussions are framed by an adult, most are initiated and sustained by the girls. 
Ms. Lana and I work to create a setting where we can develop, collectively and individually, the stamina and courage to discuss controversial or risky topics (DiAngelo \& Sensoy, 2010). Thus, the adults often say, "We don't know," or "There isn't just one answer we're looking for." While I take seriously the idea that all views are equally valid and valuable, I grapple with whether, when, and how to challenge sexist, racist, or antigay comments. Also, as a generation 1.5 immigrant woman, I share certain experiences with the girls; however, I interrogate my own positionality as an adult teaching at a university and the privileges afforded by that positionality.

\section{Methodology, Data Sources and Analysis}

The research question guiding my work is how and with what impact (on their literacies as well as their cultural, national, and global identities) immigrant girls participate in an afterschool program centered on discussing graphic novels. My research is shaped by a critical-interpretive epistemology, which privileges young people's multiple voices, experiences, and perspectives, while recognizing the ways in which those voices, experiences, and perspectives are implicated in power relations and social structures. Given this epistemological orientation, I rely primarily on ethnographic and discourse-analytic approaches.

For the purposes of this paper, I focus my analysis on transcripts of discussions about the girls' home countries and governments, the U.S. involvement in other parts of the world, and their views on life in the United States. These discussions happened in the context of reading two historical graphic novels: Barefoot Gen (Nakazawa, 1995), which narrates the life of a Japanese family leading up to the bombing of Hiroshima; and Pride of Baghdad (Vaughan \& Henrichon, 2006), which centers on the story of four lions that escape the Baghdad Zoo after an American bombing raid.

When working with the transcripts, I first read and annotate them: noting impressions, making connections to previous transcripts, and inferring what cultural models (e.g., cultural model of American meritocracy) might be at play in the discussion. Reading the transcript again, I group the turns - segments of speech in a conversation that represent a complete utterance by one speaker (Schegloff, 2000) - by topic or theme. Through this approach, I develop an overview of the salient themes in each transcript and identify specific instances where the girls discussed their identity, life in the United States, political systems, and their home countries' governments. In these discussions, the girls surfaced complex views toward the United States and their home countries, questioned injustice in the world, and explored relationships between macro systems (e.g., Communism in China) and everyday experiences (e.g., receiving food rations from the government). Analyzing these specific instances, I found that what prompted the girls' engagement with critical multicultural citizenship was sharing stories about their home country. In other words, critical multicultural citizenship began with the girls examining countries and governments outside of the United States. This is a finding which I will highlight in the next section of this article. 
I interviewed five out of the six girls. All interviews were recorded and transcribed. From the interviews, I learned how the girls conceptualized citizenship in practical terms. They said that a citizen is someone who can travel within and beyond the country, sponsor a family member, and receive financial aid for college. They also understood how citizenship has been used to include some, yet exclude others (Ladson-Billings, 2004). I also learned that speaking about and against governments was new to the girls. Parents and teachers in the girls' home countries discouraged the girls from questioning the government or taking an interest in politics. Maryam shared,

I don't remember a day where we had a conversation. I'm saying in Jordan. My Dad there too. He always letting us not have a conversation about politics and religious radicals and stuff like that.

In the next part of the paper, I illustrate how the girls, although new to publicly discussing "politics," engaged in social criticism, wrestled with the complexities of global politics, taught each other about their countries, and theorized how to make a difference in the world.

\section{Findings: Going Global and Getting Graphic}

Traditionally, citizenship education in the United States happens through history, social studies, government, and civics classes. This assumes that participation in democratic processes requires knowing something about the U.S. government and its history. I want to offer a different way of thinking about citizenship education for recentarrival immigrant youth - a way that begins with what they know about their own countries and governments, not with what they do not know yet about the United States. This way also takes seriously the value of dialogue among youth who bring not only their diverse national backgrounds, but also political and social knowledges. In an interview, Maryam talked about not knowing a lot about US history. She said, "When I came, I don't know anything about history. I still remember that she [teacher] was like talking about Lincoln. I said, 'Who is Lincoln?"'

Not knowing about Lincoln did not prevent the girls from practicing and developing a form of critical multicultural citizenship. Through sharing what they do know about their countries and the world, the girls questioned U.S. involvement in Asia, Africa, and the Middle East, and developed consciousness about injustices within and beyond the United States. To advance this argument, I draw on the girls discussing Barefoot Gen (Nakazawa, 1995) and Pride of Baghdad (Vaughan \& Henrichon, 2006).

We begin every book by sharing what we know about the setting of the text. Barefoot Gen was no exception. These were some responses:

Carla: It's in Asia

Maryam: And it's really good with technology

Carla: Their commercials are so weird. 
Jillian stayed silent while Carla and Maryam described Japanese commercials on YouTube. Then she said, "I shouldn't say it. No. No. I shouldn't say it." When encouraged to speak, Jillian continued,

Jillian: Yeah. I was very hate Japanese. Yeah. It's a very, um, I don't want to share about it 'cause, 'cause I feel very sad about it, and I feel very ashamed about it. You know it, right? You guys know it so, about the history. About Japan and Chinese people.

Carla: No, I don't know.

Maryam: I don't know anything. They don't teach us about anything about Chinese or Asian in my country.

Jillian: Well. That was like hundred years before, and um, it was a city. Its name is Nanjing. Do you know it? Do you know it, right? And there was killed the whole city people. Like three, thirty thousand peoples. They kill all the peoples in the town. And it was very, yeah, they insulting, they insulting

Maryam: So the Japanese killed the--

Jillian: Chinese. And they insulting (sic) the women. Even, there was like rap, rape. They was like rape the women on the street and they do some, they, yeah they even do some experiment in the Chinese people. They use poison. New poison they create in Chinese people. They, they even [...] even though a pregnant woman. They want to, they want to see how's the baby in pregnant women's belly and they just, they just cut, they just cut the belly and, when a women is still alive and they just take out the babies.

Jillian assumed that Maryam and Carla knew the history between Japan and China. For Jillian, Japan's treatment of China made up a central part of her history curriculum and her education as a Chinese citizen. Maryam challenged Jillian's assumptions, however. Maryam reminded Jillian that she attended a different school system-one that pays little attention to the history of East Asia. As Jillian painted a vivid picture of the Nanjing massacre, Maryam questioned how Jillian learned about this and whether videos and books about the event exist.

\section{Critiquing Governments}

As a Chinese national, Jillian had internalized her homeland's dominant stance toward Japan-namely that all Japanese are cruel. However, throughout the two months of discussing Barefoot Gen, the girls, including Jillian, developed a more complex understanding of Japan and global warfare. For example, in one panel, a Japanese soldier kicks a boy for eating a potato. Jillian pointed to the injustice of a soldier wearing expensive leather boots, while people are starving. Over time, Jillian revised her stance. Rather than hate Japanese people, she critiqued the Japanese 
government for sacrificing the wellbeing of its citizens for power and national pride. She also became more aware of the diversity within the Japanese population, realizing that some Japanese citizens were against its government.

Jillian: I think, it's, uh, their government. They had hurt our, they hurt our country before. But I can, I can also feel the same way, how the, how the people feel when they, during the war, so that's why I hate the government because the government always want, the government always want sacrifice their people.

Maryam: Yeah, my Mom always said that we've been to war a lot. And she always say that Iraqi people are, they live not a fair life because of their leaders, they put them in wars and they are, like, innocent. And a lot of innocent people die, without doing anything, just because of leaders and just because of political things.

Danielle: Kinda reminds me of DR [Dominican Republic].

Maryam: Why?

Daniele: DR used to be like a. I forgot. What's his?

Carla: Trujillo.

Danielle: Trujillo. Yeah. He was the president? So people couldn't talk about him cause then the, the police people? The security that he had would be around the houses. People barely went out. They barely went out.

Jillian's critique of the Japanese government created a space for others to describe their homeland's governments. Danielle and Carla named the oppressive practices under Rafael Trujillo, who had ruled the Dominican Republic. Danielle described how people's speech and actions were regulated by the military. She then described the imprisonment and torture of anyone that defied Trujillo. Through sharing, the girls realized that oppression and abuses of power occur in different nation-states and under different presidents, including Trujillo and Sadam Hussein.

In addition to exploring the abuses of their own government, they began to grapple with the disparities in their home countries. The next transcript comes from the girls' discussion of the second historical graphic novel: Pride of Baghdad. The girls viewed a panel where the lions enter an abandoned mansion. They wondered what kind of a person may have lived there. Monique hypothesized that the mansion belonged to a corrupt government official, adding that the mansions looked like the ones owned by Nigerian government officials. She explained,

Monique: We have cocoa. So much cocoa. I think Nigeria is like number three producing cocoa. Ghana is like number two, and Côte d'Ivoire is number one. So we have that wealth. But our government, they keep gathering everything to themselves. Like these people are really rich. Their children don't go to school in Nigeria. Seventy percent of my country is poverty, and they have money. I know they have so much money. And their children, all of them, they're in America, Australia, UK. They're living a very exotic life, and the people are just suffering. 
Jillian: Yeah. You know there are, there are many many people in China don't have food. And they don't even have electricity in their house. Usually only live in the mountain, like very deep in the mountain. You know, 'cause my, my brother-in law's parents, they live in the, like, little village on the countryside, so their house is kind of very very bad and broke. All the walls are broken. And you know what government do? Government built a wall between city and like, in front of the countryside so the people, so that some people go to visit this country so they wouldn't see what's inside of the wall. They only see the city. So that's why. So that's why people say China is a wealthy country or something. But it's not. It's really not.

Jillian and Monique turned their critical gaze to their home countries. In the exchange above, Jillian criticized the Chinese government for hiding the poverty that exists outside of cities like Shanghai and Beijing. She suggested that the Chinese government created a wall so that tourists would see the façade of wealth. The wall made it difficult for villagers to access the resources of the city. Similarly, Monique, while expressing pride in being Nigerian, condemned a system where citizens benefit unequally from the country's natural resources. She questioned how it is possible that Nigeria can be home to some of the wealthiest individuals in the world, yet have 70 percent of its population live in poverty. Rather than blind patriotism, the girls called into question the inequities in their countries, practicing a form of critical reflection and consciousness (Castro, 2009).

\section{Exploring US Involvement in the World}

In the afterschool program, the girls cultivated their dual frames of reference (Suárez-Orozco \& Suárez-Orozco, 2001), focusing on not only their homeland, but also the United States and the relationship between the United States and their home countries. Cultivating this dual perspective is important to citizenship education, which has to help students see the interdependence among nations (Banks, 2004). Pride of Baghdad depicts the impact of U.S. involvement in Iraq. Thus, it is not surprising that the girls wanted to understand why the United States bombed Iraq. The discussion below was prompted by Maryam's comment that Iraqis viewed Americans as either saviors or destroyers.

Maryam: Some people didn't like American. They didn't like that they came and they said that they killed a lot of people. But a lot, a lot of Iraqis said that Americans helped them.

Jillian: But, but I think, I think invaded. 'cause you use force to go that country. But, um, but American is use the, what's that called? Oh, oh, use the tank. Use the tank to go to their country so it's force.

Cleo: $\quad$ To go to this country [Iraq] and go destroy them. So why do America have this thing they need to do? 
Maryam: I used to watch videos and see, like, or news. Like see a lot of people dying, and I wasn't knowing who killed those. I was thinking, "Oh my God. There is war. We're good and they're bad." I used to think that they came to war because they hate us, not because of the Sadam Hussein, and they wanted to, like, save us from him.

Maryam, whose own family had fled Baghdad, was the only one who defended the United States' decision to invade Iraq. Jillian, Carla, and Cleo condemned the United States for using force and destroying a country. The girls debated whether any country can justify military intervention, and what kinds of rights and responsibilities one country has towards another. Monique asked if the United Nations approved of the United States entering Iraq. She also challenged the logic behind the argument that the United States entered Iraq to promote peace. She said, "But killing another country's president could actually cause a war between two countries." Lastly, Carla pointed out what she perceived to be an inconsistency in the foreign policy of the United States. She asked why the United States can use force in some countries, but not in others like North Korea.

More often than not, we did not reach neat or tidy answers to these questions. In fact, Danielle, in our last meeting for Barefoot Gen, expressed frustration

Danielle: You know something. I feel like we're safer when we don't know a lot of things because I feel like the more we know, what if you can't decide what you believe? You know what l'm saying. Everything is challenging itself. I'm like, how can it be this, but yet that. And when I find something, then I find something else.

According to Danielle, it might be safer to be told what to believe and to have certainty than it is to challenge everything. Moving beyond thinking in dichotomies, Danielle recognized that something can be both "this, but yet that." The idea that many things in the world, including nation-states, are "this, but yet that" appeared in the girls' understanding of the United States.

\section{"United States is the Best Country": Grappling with the Realities of their New Home}

None of the girls believed that the United States is all good or all bad. They described the United States as better than other countries in some ways, but worse in other ways. Cleo argued that the United States is the best country for her. As evidence, she drew on her experiences in Mali, where citizens have to bribe police officers for protection against rebel militia, and in France, where her family members live in fear because they don't have their "identification."

Cleo: You can come in here, you go to the court, you can fight for your case, but in France, if they, if they, nothing. Here you don't have green card, your residency, nothing, you can walk in the street. If you want to go to New York, if you want go to whatever place you want, you can, but in 
France you can't do it. You can't do it. You can't walk if you don't have your identification.

The girls believed that everyone in the United States can go to school and receive medical care. However, they also understood that undocumented citizens do not get the same kind of benefits as "legal" residents. Cleo said, "Everyone is welcome in the United States. That true." This comment sparked a dialogue, which surfaced the contradictions in how the girls understood the country's stance on immigration.

Jillian: No. I don't think so. That's not true.

Jie: What about all those people who are being deported?

Monique: I think that one, it's a normal phenomenon. It's general. It happens in every country. That it deports people, like in different countries. Just because you don't know about it, but it's general in every country. They deport everywhere. It's not a new thing.

Cleo: I never, I never, I never hear of my country that someone go and they deported.

Monique: You never hear Americans go to African country and they deported. When the white people come to our country, we worship them. We make them feel happy. But when we go to their country, it looks like we're nobody.

Monique suggested that deportation has been going on for a long time, in every country. She implied that the United States, though priding itself as a country of immigrants, is no different from other countries. I noted how the girls were questioning who gets deported and who gets to deport others. They wondered why it is that we never hear of an American (i.e., White person) getting deported from Africa. Cleo and Monique understood that people who are seen as having more power and value are less likely to get deported.

Monique equated Americans as being White. According to Castro (2009), traditional citizenship education can work against democratic participation by avoiding explicit discussions of race and racism. Monique pointed to how Whites, who are "worshipped" in Africa, marginalize Africans who enter their country. Cleo and Monique acknowledged that race shapes how one is treated in many parts of the world, including the United States. The girls valued the opportunity to discuss race and racism. In the interview, Jillian said that there is very little talk about racism and discrimination in her classes, including her history class. She said, "We don't talk about it. We only learned about Constitution."

\section{Revolutions or Elections: Theorizing Change}

As a form of justice-oriented citizenship education, critical multicultural citizenship is committed to the creation of more socially just spaces, communities, and worlds (Westheimer \& Kahne, 2002). The creation of more just worlds involves moving beyond 
critical commentary and working towards transformation. Although the afterschool program did not include any explicit components for enacting change at the individual or community level, it created a space to wrestle with where change comes from and to question the extent to which people can change governments and institutions.

In discussing Barefoot Gen, Jillian expressed admiration for Gen's father, who challenged Japan's involvement in the war. She wondered why more Japanese citizens were not like Gen's father. Danielle responded that most people passively conformed to and followed the masses.

Danielle: I feel like so many people are following, you know. How can I say it, like, they're following the rules because some people are, like, afraid, so they conform. They agree or just go with them.

Jillian: It's all involve with government. How the government wants to tell the people how the other country is because the government always said how bad the other people. So um, so I think it's only when the government change their mind.

Maryam: That will fix the whole problem 'cause the whole problem is from the government. The government makes them think that way.

Jillian and Maryam believed that the government has to change in order for its people to change. I noted how the girls named the government as something "out there," an entity that influences how people think and act. In other words, the girls did not see themselves as part of the government, nor did they describe themselves as agents who could change the government from within. Jillian even said, "We are too powerless. We can't do anything," to which Cleo agreed. When I asked the girls how governments change, Jillian responded,

Jillian: Revolution

Monique: And vote. If you vote, you can change them. Yeah, like vote for the person you want. Change them. But elections are never free and fair.

Jie: $\quad$ How is it never free and fair?

Monique: Like, they will turn it into a family thing. So everybody from the family is in politics. You see the president's wife is a senator. The president's son is this. Like, they don't make the thing go out to other people.

Monique described how in the 2016 U.S. presidential elections, several candidates are related to past presidents. She critiqued this as a way of keeping power within a family, effectively creating family dynasties within a democracy. I saw this as an instance of Monique practicing a form of critical multicultural citizenship since she recognized the gaps between the ideal of democracy and its actual practices (Banks, 2004). Instead of an overly romanticized belief in the power of voting, Monique pointed to the limitations of voting as a mechanism for systemic change. Castro (2009) makes the distinction between individual choices and larger collective action and suggests that both are important for social transformation. Although the girls did not use the language of "individual choices" and "collective action," they grappled with the role of each through their discussions about whether change happens through elections or revolutions. 
To summarize, the afterschool program enabled the girls to explore the interdependence among nation-states, wrestle with the complexities of their new home country, question government structures, and draw connections between micro (everyday) experiences and macro-structures. There was participation rather than silence about the world, each other, and themselves. In the afterschool program, the girls found and developed their insurgent voices (Valdés, 1998), questioning the way things are done in different parts of the world and exploring the possibility of change for the marginalized and oppressed.

\section{Conclusion: A Note for Educators}

Unlike traditional civic education, critical multicultural citizenship education offers no checklist or set strategies. However, analysis of the girls' discussions in the afterschool program offers several principles that can guide teachers who are working towards critical multicultural citizenship education.

First of all, critical multicultural citizenship education can benefit from the inclusion of multimodal texts (e.g., graphic novels, picture books, digital stories) that expand on and offer alternatives to textbooks or other forms of school-sanctioned knowledge. Graphic novels are a particularly rich resource for recent-arrival immigrant youth since they possess the "inherent ability to provide visual scaffolding" (Gomes \& Carter, 2010, p. 68). Moreover, graphic novels often tell human stories from a specific historical, social, and ideological vantage point. Danielle described these human stories as having powerful meaning. As I have illustrated, such texts can motivate sophisticated political dialogue.

In addition to using different kinds of texts, educators can work to create democratic settings where students deliberate and collaborate with classmates who are diverse in terms of nationality, race, gender, religion, language backgrounds, and worldviews. In an interview, Maryam shared that her history teacher would often just lecture about democracy: "When I came here, I heard about Congress, and the law and who passes the law for who. It was always a nightmare." A pedagogy of telling undermines critical multicultural citizenship education. Instead, its possibilities emerge in dialogue and from the knowledges that young people bring from their diverse global experiences.

I acknowledge that this was an afterschool program, without any time and curriculum constraints or accountability requirements-factors that often work against dialogue-rich classrooms. However, rather than reinforce in-school and out-of-school dichotomies, I believe, like others (see Skerrett \& Bomer, 2011) that out-of-school and afterschool spaces are valuable sites for teacher and researcher learning. Because students develop identities and literacies across multiple contexts, it is important for teachers and researchers to learn from out-of-school settings, where students make connections to the in-school learning and to other parts of their lives.

Lastly, critical multicultural citizenship education requires a shift in the consciousness of the educators themselves, who must examine their assumptions 
about the capacities of culturally and linguistically diverse youth. The power of the girls' voices in the afterschool program challenges deficit views that English learners cannot engage in creative, analytical, and critical communication. Not only can they, but the diverse knowledges they shared deepened everyone's ability to engage with the complexities of global politics. This shift also requires educators to grapple with what it means to live a life characterized by diversity and how to build, individually and collectively, a more just nation-state and world.

\section{Notes}

1. The absence of dialogue is not unique to schools in the United States. The girls featured in this article, who attended school in China, Dominican Republic, Ghana, Nigeria, Mali, and Jordan, described an approach to education where teachers lectured and students listened and memorized for exams.

2. So far, we have read the following graphic novels: Rapunzel's Revenge (Hale, Hale, \& Hale, 2008); Beautiful Creatures (Garcia, Stohl, \& Cassandra, 2013); Barefoot Gen (Nakazawa, 1995); The League of Extraordinary Gentlemen (Moore, 2000); Pride of Baghdad (Vaughan \& Henrichon, 2006); Uglies (Westerfield Grayson, \& Cummings, 2012).

\section{References}

Abowitz, K. K., \& Harnish, J. (2006). Contemporary discourses of citizenship. Review of Educational Research, 76(4), 653-690.

Abu El-Haj, T. R. (2007). "I was born here, but my home, it's not here": Educating for democratic citizenship in an era of transnational migration and global conflict. Harvard Educational Review, 77(3), 285-316.

Banks, J. A. (2004). Democratic citizenship education in multicultural societies. In J.A. Banks (Ed.), Diversity and citizenship education: Global perspectives (pp. 3-15). San Francisco, CA: Josey-Bass.

Carter, J. B. (2007). Building literacy connections with graphic novels: Page by page, panel by panel. Urbana, IL: National Council of Teachers of English.

Castro, A. J. (2009). Promoting critical multicultural citizenship: A case study of preparing social studies teachers. The University of Texas at Austin: Unpublished doctoral dissertation.

Delgado, R. (1998). Storytelling for oppositionists and others. In R. Delgado \& J. Stefancic (Eds.), The Latino/a condition: A critical reader (pp. 259-270). New York, NY: New York University Press.

DeNicolo, C. P., \& Franquiz, M. E. (2006). "Do I have to say it?": Critical encounters with multicultural children's literature. Language Arts, 48(2), 157-170. 
DiAngelo, R., \& Sensoy, Ö. (2010). "Ok, I get it! Now tell me how to do it!": Why we can't just tell you how to do critical multicultural education. Multicultural Perspectives, 12(2), 97-102.

Dilworth, P. P. (2004). Multicultural citizenship education: Case studies from social studies classrooms. Theory and Research in Social Education, 32(2), 153-186.

Freire, P. (1987). The importance of the act of reading. In P. Freire \& D. Macedo (Eds.), Literacy: Reading the word and the world, (pp. 5-11). South Hadley, MA: Bergin and Garvey.

Freire, P. (1999). Pedagogy of the oppressed. New York, NY: Continuum.

Giroux, H. A. (2004). Critical pedagogy and the postmodern/modern divide: Towards a pedagogy of democratization. Teacher Education Quarterly, 31(1), 31-47.

Gomes, C., \& Carter, J. B. (2010). Navigating through social norms, negotiating place: How "American Born Chinese" motivates struggling learners. English Journal, 100(2), 68-76.

Hooks, B. (1994). Teaching to transgress: Education as the practice of freedom. New York, NY: Routledge.

Fu, D., \& Graff, J. M. (2009). The literacies of new immigrant youth. In L. Christenbury, R. Boomer, \& P. Smagorinsky (Eds.), Handbook of adolescent literacy research (pp. 400-414). New York, NY: The Guilford Press.

Kincheloe, J. L. (2008). Critical pedagogy primer. New York, NY: Peter Lang.

Ladson-Billings, G. (2004). Culture versus citizenship: The challenge of racialized citizenship in the United States. In J. A. Banks (Ed.), Diversity and citizenship education: Global perspectives (pp. 99-126). San Francisco, CA: Josey-Bass.

Levine, P., \& Higgins-D'Alessandro, A. (2010). Youth civic engagement: Normative issues. In. L. R. Sherrod, J. Torney-Purta, \& C.A. Flanagan (Eds.), Handbook of research on civic engagement in youth (pp. 115-137). Hoboken, NJ: John Wiley \& Sons.

McLaren, P. (1997). Revolutionary multiculturalism: Pedagogies of dissent for the new millennium. Boulder, CO: Westview Press.

Nakazawa, K. (1995). Barefoot gen: A cartoon story of Hiroshima: Vol. 1. New York, NY: Penguin Books.

Nieto, S. (2002). Language, culture, and teaching: Critical perspectives for a new century. Mahwah, NJ: Lawrence Erlbaum.

Salinas, C., Sullivan, C., \& Wacker, T., (2007). Curriculum considerations for late-arrival high school immigrant students: Developing a critically conscious World Geography Studies approach to citizenship education. Journal of Border Educational Research, 6(2), 55-67.

Schegloff, E. A. (2000). Overlapping talk and the organization of turn-taking for conversation. Language in society, 29(1), 1-63. 
Schoem, D. (2003). Intergroup dialogue for a just and diverse democracy. Sociological Inquiry, 73(2), 212-227.

Serafini, F. (2011). Expanding perspectives for comprehending visual images in multimodal texts. Journal of Adolescent \& Adult Literacy 54(5), 342-350.

Skerrett, A., \& Bomer, R. (2011). Borderzones in adolescents' literacy practices: Connecting out-of-school literacies to the reading curriculum. Urban Education, 46(6), 1256-1279.

Sleeter, C. E., \& Bernal, D. D. (2004). Critical pedagogy, critical race theory, and antiracist education: Implications for multicultural education. In J.A. Banks \& C.A.M. Banks (Eds.), The handbook of research on multicultural education (pp. 240-258). San Francisco, CA: Josey-Bass.

Suárez-Orozco, C., \& Suárez-Orozco, M. (2001). Children of immigration. Cambridge, MA: Harvard University Press.

Suárez-Orozco, C., Suárez-Orozco, M., \& Todorova, I. (2008). Learning a new land: Immigrant students in American Society. Cambridge, MA: Belknap Press.

Valdés, G. (1998). The world outside and inside schools: Language and immigrant children. Educational Researcher, 27(6), 4-18.

Vaughan, B. K., \& Henrichon, N. (2006). Pride of Baghdad. New York, NY: DC Comics.

Westheimer, J., \& Kahne, J. (2002). What kind of citizen? The politics of educating for democracy. Paper presented at the Annual Meeting of the American Educational Research Association. New Orleans, LA.

\section{Author Contact}

Jie Y. Park: jiepark21@gmail.com

Clark University

950 Main Street

Worcester, MA 01610

U. S. A. 